\title{
Węzeł hybrydowy - prognozowanie odkształceń spawalniczych panelu I-core na podstawie planowanego eksperymentu dwuwartościowego
}

\author{
Hybrid node - predictions of welding distortions \\ of I-core panel on the basis of two dimensional \\ designed experiment
}

\section{Streszczenie}

W artykule przedstawiono wyniki badań eksperymentalnych czterech postaci odkształceń spawalniczych panelu I-core. Panel ten jest częścią węzła hybrydowego. Badania przeprowadzono wg zasad teorii planowania eksperymentu w warunkach laboratoryjnych, zbliżonych do warunków panujących w przemyśle. Przedstawiona analiza postaci deformacyjnych uwzględnia parametry technologiczno-konstrukcyjne wpływające na przydatność montażową wielkogabarytowej konstrukcji stalowej. Omówiona metoda oceny wyników eksperymentalnych umożliwia wykorzystanie wzorów aproksymacyjnych w celu prognozowania analizowanych postaci odkształceń w konstrukcjach wielkogabarytowych.

\section{Wstęp}

Węzet hybrydowy to szczególny fragment wielkogabarytowej konstrukcji stalowej, w którym łączą się dwie odmienne pod względem konstrukcyjno-technologicznym części tej konstrukcji. W jego skład wchodzą: innowacyjny element konstrukcyjny (zwany powszechnie panelem sandwich), konwencjonalny element konstrukcyjny (płyta usztywniona) oraz element pośredni (łącznik) [1].

Kształty łączników, które mogą być wykorzystane $\mathrm{w}$ połączeniach paneli sandwich, są różne $[2 \div 4]$. Do badań autora wybrano łącznik o kształcie

Dr inż. Tomasz Urbański - Zachodniopomorski Uniwersytet Technologiczny w Szczecinie.

\section{Abstract}

The paper presents the results of experimental research on four types of welding distortions of I-core panel. This panel is a part of a hybrid node. The research has been carried out according to design of experiment technique in laboratory conditions near-real-life production conditions. The presented analysis of deformation picture accounts for technological-constructional parameters influencing the suitability for assembly of large-size steel construction. The presented appraisal method used for experiment results features implementation of approximation formulas in order to predict analysed types of distortions in large-size constructions. przedstawionym na rysunku 1 . Szczegółową analizę, dotyczącą wyboru geometrii tego elementu, zawarto w [2].

Węzeł hybrydowy może znaleźć zastosowanie wszędzie, gdzie wykorzystywane są innowacyjne elementy konstrukcyjne. Natomiast panele sandwich, jako elementy wielkogabarytowych konstrukcji stalowych, mogą być użyte przede wszystkim w rejonach konstrukcji nie posiadających krzywizn [1].

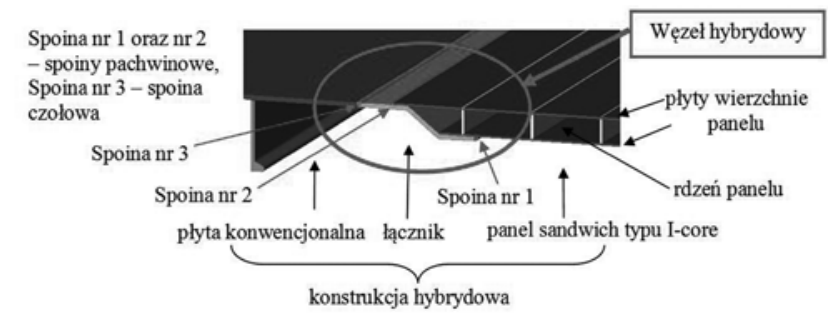

Rys. 1. Węzeł hybrydowy [2]

Fig. 1. Hybrid node [2] 
Wprowadzenie węzła hybrydowego do wielkogabarytowych konstrukcji spawanych sprawia wiele problemów, zwłaszcza natury technologicznej. Za najbardziej istotny z nich, zarówno od strony naukowej, jak i przemysłowej, uznano opanowanie odkształceń spawalniczych.

Brak jest dostępnych publikacji poruszających aspekty związane z technologicznością konstrukcji zawierającej panele I-core w kontekście jej dalszej przydatności montażowej [2]. W dotychczasowych badaniach skupiano się przede wszystkim na problemach związanych z samymi panelami sandwich, tj.: ich ogól-

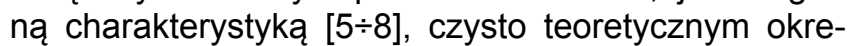
ślaniem wskaźników wytrzymałościowych $[9,10]$, wytrzymałością na różnego typu obciążenia [6, 7, 11, 12],

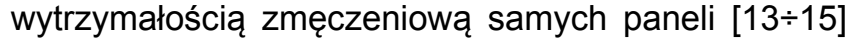
oraz wybranych rozwiązań połączeń głównie panel-panel $[6,7,16,17]$ oraz innymi aspektami, ujawniającymi się na etapie eksploatacji konstrukcji, jak np. odporność ogniowa, udarowa, korozyjna, tłumienie drgań, możliwości naprawy [6, 7, 18, 19].

Brak dostępnych analiz dotyczących zachowania deformacyjnego konstrukcji hybrydowej w ujęciu technologicznym był przyczynkiem do podjęcia badań eksperymentalnych. Prowadzone rozważania są częścią kilkuletnich dociekań naukowych autora nad problemem technologiczności węzła hybrydowego, których efekt końcowy stanowi rozprawa [2]. Badania eksperymentalne wykonano na Wydziale Techniki Morskiej (obecnie Wydział Techniki Morskiej i Transportu) Zachodniopomorskiego Uniwersytetu Technologicznego w Szczecinie w latach $2007 \div 2009$.

\section{Odkształcenia spawalnicze paneli I-core w węźle hybrydowym}

Problematyka dotycząca wyznaczania, prognozowania i w konsekwencji opanowania odkształceń spawalniczych rozważana jest od początku wprowadzenia spawania jako metody łączenia elementów metalowych. Obecnie inżynier może korzystać z obszernej literatury fachowej, naświetlającej różne aspekty fizyczne tego zjawiska $[20 \div 23]$. Jednak nowe elementy konstrukcyjne oraz obszary, w których one występują (np. węzeł hybrydowy), wciąż wymagają wnikliwej analizy zagadnień deformacyjnych, zarówno od strony eksperymentalnej, jak i teoretycznej.

Postacie odkształceń spawalniczych powstałych przy wykonywaniu spoin wchodzących w skład analizowanego węzła hybrydowego zidentyfikowano w [1, 2]. Spośród piętnastu postaci odkształceń z panelem I-core związane są cztery (tabl. I). Celem łatwiejszej lokalizacji wyróżnionych form deformacji przyporządkowano je poszczególnym spoinom węzła (rys. 1). Pomimo że wykonanie spoiny nr 3 ma również wpływ na końcową wartość deformacji panelu, nie zostało
Tablica I. Odkształcenia spawalnicze panelu I-core wyróżnione w węźle hybrydowym [1, 2]

Table I. Welding distortions of I-core panel distinguished in hybrid node $[1,2]$

\begin{tabular}{|c|l|c|}
\hline $\begin{array}{c}\text { Numer } \\
\text { spoiny } \\
\text { węzła } \\
\text { hybrydowego }\end{array}$ & $\begin{array}{c}\text { Odkształcenia spawalnicze wyznaczane } \\
\text { eksperymentalnie }\end{array}$ & $\begin{array}{c}\text { Symbol } \\
\text { postaci od- } \\
\text { kształcenia }\end{array}$ \\
\hline 1 & $\begin{array}{l}\text { odkształcenie wzdłużne poszycia pa- } \\
\text { nelu (strzałka ugięcia) }\end{array}$ & DWP1 \\
\hline 2 & $\begin{array}{l}\text { odkształcenie wzdłużne poszycia pa- } \\
\text { nelu (strzałka ugięcia) }\end{array}$ & DWP2 \\
\hline 1 & $\begin{array}{l}\text { odkształcenie poprzeczne poszycia } \\
\text { panelu (pofalowanie powierzchni) }\end{array}$ & DPP1 \\
\hline 2 & $\begin{array}{l}\text { odkształcenie poprzeczne poszycia } \\
\text { panelu (pofalowanie powierzchni) }\end{array}$ & DPP2 \\
\hline
\end{tabular}

to uwzględnione w artykule, gdyż problem ten będzie omawiany w odrębnym tekście.

Przedstawione w tablicy I postacie odkształceń spawalniczych wpływają na dalszą przydatność montażową węzła hybrydowego, a DWP1 oraz DWP2 w sposób najbardziej znaczący [2]. Zajmują one bowiem odpowiednio pierwszą oraz drugą pozycję w tzw. hierarchii technologicznej postaci odkształceń spawalniczych węzła. Hierarchię tę stworzono celem uszeregowania analizowanych form deformacji pod kątem ich wpływu na przydatność montażową. DPP1 oraz DPP2 zajmują piątą oraz siódmą pozycję w przytaczanej hierarchii (szczegółową analizę, dotyczącą wpływu wszystkich postaci odkształceń spawalniczych węzła hybrydowego na jego technologiczną przydatność montażową, zawarto w [2]).

Wszystkie postacie deformacji powstałe na powierzchni innowacyjnych elementów konstrukcyjnych (tabl. I) są wyjątkowo istotne $z$ uwagi na ogromne trudności związane zarówno z zapobieganiem odkształceniom, ich prognozowaniem, jak i ewentualnymi pracami naprawczymi (tj. głównie prostowaniem) tych elementów (specyficzna struktura oraz bardzo cienkie blachy paneli sandwich w stosunku do pozostałych elementów wielkogabarytowej konstrukcji) [2].

\section{Badania}

Główne założenia oraz cel, jaki postawiono badaniom eksperymentalnym węzła hybrydowego, przedstawiono $\mathrm{w}$ tablicy II, natomiast materiały wykorzystane $\mathrm{w}$ doświadczeniach zestawiono $\mathrm{w}$ tablicy III.

Eksperymenty wykonano na stanowisku, w którego skład wchodziło tzw. łoże montażowe (o wymiarach $4500 \times 2000 \times 480 \mathrm{~mm}$ ) oraz elementy zamocowania próbek, symulujące założone postacie warunków brzegowych - elementy te były jednocześnie detalami ustalającymi położenie próbek względem łoża (rys. 2). Na panel I-core nałożono warunek brzegowy w postaci przegubowo-nieprzesuwnego podparcia panelu. Jest to zgodne z powszechnie obowiązującymi 
Tablica II. Założenia oraz cele badań eksperymentalnych węzła hybrydowego [2]

Table II. Assumptions and aims of experimental studies of hybrid node [2]

\begin{tabular}{|l|l|}
\hline \multicolumn{1}{|c|}{ Założenia badań } & \multicolumn{1}{|c|}{ Cele badań } \\
\hline $\begin{array}{l}\text { Warunki badań możliwie jak naj- } \\
\text { bardziej zbliżone do warunków } \\
\text { produkcyjnych }\end{array}$ & $\begin{array}{l}\text { Wyznaczenie zidentyfikowanych } \\
\text { postaci odkształceń (tabl. I) }\end{array}$ \\
\hline $\begin{array}{l}\text { Wykonywanie prac spawalni- } \\
\text { czych przez spawacza posia- } \\
\text { dającego odpowiednie upraw- } \\
\text { nienia, przy wykorzystaniu me- } \\
\text { tod oraz urządzeń powszechnie } \\
\text { stosowanych przy wytwarzaniu } \\
\text { wielkogabarytowych konstrukcji } \\
\text { stalowych }\end{array}$ & $\begin{array}{l}\text { Opracowanie modeli } \\
\text { predykcyjnych }\end{array}$ \\
\hline $\begin{array}{l}\text { Prowadzenie badań wg zasad } \\
\text { teorii planowania eksperymentu }\end{array}$ & \\
\hline
\end{tabular}

Tablica III. Materiały użyte do badań [2]

Table III. Materials used to studies [2]

\begin{tabular}{|l|l|}
\hline \multicolumn{1}{|c|}{ Materiały podstawowe } & \multicolumn{1}{|c|}{ Materiały dodatkowe } \\
\hline Stal AH36 na łącznik & $\begin{array}{l}\text { Drut proszkowy K-71TLF firmy } \\
\text { Kiswel, o średnicy 1,2 mm }\end{array}$ \\
\hline $\begin{array}{l}\text { Stal S355 (J2G3) na płyty } \\
\text { wierzchnie panelu I-core }\end{array}$ & $\mathrm{CO}_{2}$ jako gaz osłonowy \\
\hline $\begin{array}{l}\text { Stal S235 (JR) na elementy } \\
\text { rdzenia panelu l-core }\end{array}$ & \\
\hline
\end{tabular}

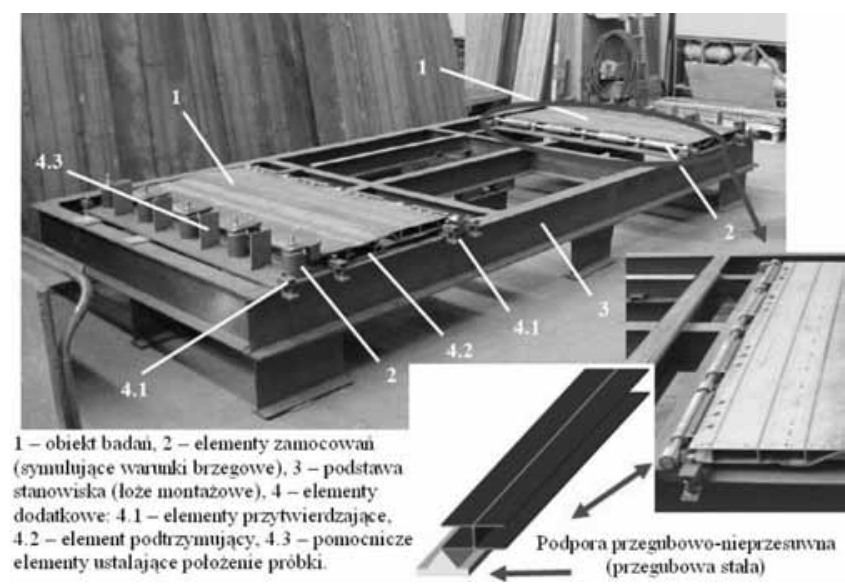

Rys. 2. Stanowisko badawcze [2]

Fig. 2. Research stand [2]

zasadami technologii wytwarzania wielkogabarytowych konstrukcji stalowych (np. okrętowych). Panel sandwich zastępuje fragment płyty poszycia, usztywnionej jednorzędowo, do której montowane są pozostałe elementy konstrukcji. Zatem zastosowane zamocowanie panelu reprezentuje dalsza część innowacyjnego elementu konstrukcyjnego [2]. Ponieważ w niniejszym artykule analizowane są tylko odkształcenia panelu I-core powstałe po wykonaniu spoin nr 1 oraz nr 2 węzła hybrydowego (tj. $w$ innowacyjnym module konstrukcyjnym), pominięto w nim charakterystykę warunku brzegowego nałożonego na płytę konwencjonalną (rys. 1).

Podczas badań wykorzystano: źródło prądu BLACK CAT 400 ST oraz zespół podający ZP S-1 (oba

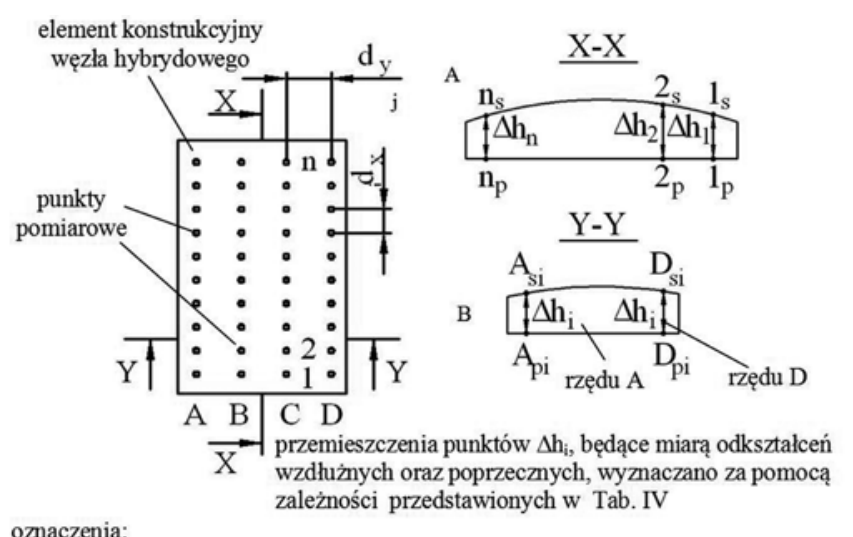

$\Delta \mathrm{h}_{\mathrm{i}}$ - różnica odleglości miẹdzy punktami pomiarowymi w kierunku pionowym przemieszczenie punktu pomiarowego $(\mathrm{i}=1, \ldots, \mathrm{n})$,

$\mathrm{A}_{\mathrm{pi}}, \mathrm{A}_{\mathrm{si}}, \mathrm{D}_{\mathrm{pi}}, \mathrm{D}_{\mathrm{si}}$ - punkty pomiarowe wzdluż danego rzędu siatki. Indeks dolny, $\mathrm{p}$, oznacza wartość przed spawaniem: indeks. $s$ - po spawaniu $(i=1 \ldots n)$.

Rys. 3. Metoda wyznaczania odkształceń: A - wzdłużnych, B - poprzecznych [2]

Fig. 3. Determinate of distortions method: A - longitudinal, B - transverse [2]

urządzenia firmy Ozas - obecnie Esab). Próbki spawano metoda 136 (przez spawacza z kilkunastoletnim doświadczeniem zawodowym w przemyśle stoczniowym). Jako narzędzie pomiarowe wykorzystano niwelator libelowy NI 004. Przyrząd ten jest niwelatorem precyzyjnym, z płytką płasko-równoległą.

Metode wyznaczania analizowanych odkształceń przedstawiono na rysunku 3 oraz w tablicy IV. Rzeczywiste wymiary próbki oraz kolejność operacji technologicznych realizowanych podczas wykonywania innowacyjnego modułu konstrukcyjnego (tj. panelu l-core oraz łącznika) na stanowisku badawczym przedstawiono na rysunku 4.

Planowanie eksperymentu realizowano na podstawie podejścia cybernetycznego, rozpatrując obiekt badań tzw. czarną skrzynkę (rys. 5). Na wejściu skrzynki wprowadzano celowo wyselekcjonowane parametry (zmienne niezależne), odpowiedzialne za powstawanie deformacji (w opisywanym przypadku: c, e, $g_{2}, q_{1}$ ). Na jej wyjściu rejestrowano odpowiedzi (zmienne zależne) od wprowadzonych parametrów ( $w$ analizowanym przypadku: DPP1, DPP2, DWP1, DWP2). Z czarną skrzynką związane są jeszcze dwie grupy wielkości - czynniki zakłócające oraz czynniki stałe, ale ponieważ nie sa one wielkościami sterowalnymi ani mierzalnymi (w sposób jawny), uznano je za mniej istotne.

W przypadku wyboru trzech zmiennych niezależnych, których wartości mogą być zmieniane na dwóch poziomach (wartość minimalna oraz maksymalna) - eksperyment przeprowadzano na podstawie planu frakcyjnego dwuwartościowego [24, 25].

Plan opisywanego eksperymentu pokazano $\mathrm{w}$ tablicy V. Liczba eksperymentów w jednym (wymaganym) bloku wynosi 8 . Wartości minimalne i maksymalne zmiennych niezależnych odpowiadają rozpiętością wyselekcjonowanym parametrom technologiczno-konstrukcyjnym. W zależności od objętości danych blok tych 8 eksperymentów może być realizowany wielokrotnie. 
Spotykane w praktyce zależności między zmiennymi eksperymentalnymi mają charakter korelacyjny. Dlatego metodę wykorzystywaną do prognozowania odkształceń spawalniczych węzła hybrydowego oparto na analizie modeli regresji zmiennych zależnych względem zmiennych niezależnych.

Przy opracowywaniu wyników badań kierowano się

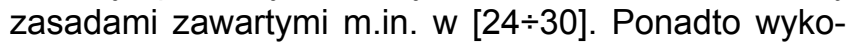
rzystano pakiet wspomagający analizę statystyczną STATISTICA.
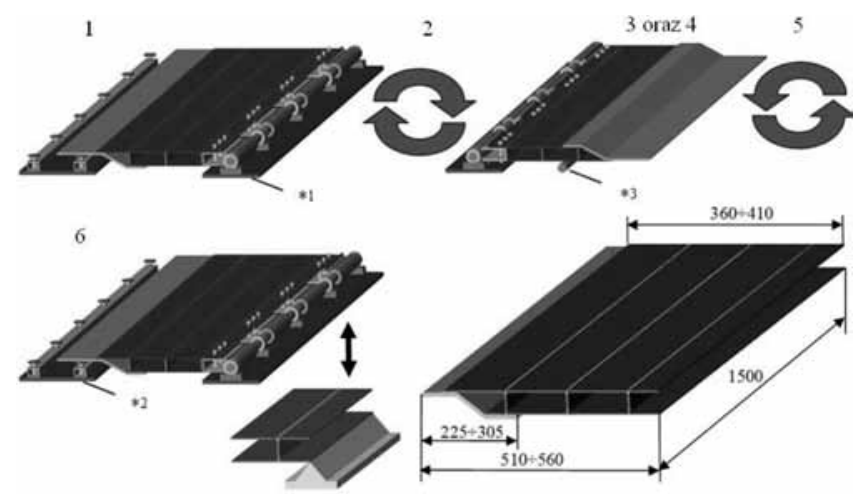

1,2,3- dopasowanie elementów oraz wykonanie spoin sczepnych po obu stronach probki.

4-wykonanie spoiny ur 1 (Rys. 1). 5 -obrót innowacyjnego modulu

konstrukcyjnego.

6-wykonanie spoiny nr 2 (Rys. 1)

"1 - postacie rzeczywiste warunku brzegowego

.2 - elementy dodatkowe (podtrzymujace) pomagajacce w ustaleniu prawidlowego polozenia probki

polozenia probki jucy problew tej san plaszczyżnie

Rys. 4. Tworzenie innowacyjnego modułu konstrukcyjnego - operacje technologiczne związane z wykonywaniem poszczególnych spoin [2] Fig. 4. Assembly of innovative constructional module - technology operations in the making of particular welds [2]

Tablica IV. Zależności matematyczne wykorzystywane przy wyznaczaniu postaci odkształceń spawalniczych [2]

Tabl. IV. Mathematical dependence used for determinate types of welding distortions [2]

\begin{tabular}{|c|c|}
\hline Opis & Wzór \\
\hline $\begin{array}{l}\text { Średnia (arytmetyczna) } \\
\text { różnicy odległości między } \\
\text { punktami pomiarowymi, } \\
\text { mierzona w kierunku pio- } \\
\text { nowym (wysokość) }\end{array}$ & $h=\frac{1}{n} \cdot \sum_{i=1}^{n} \Delta h_{i}$ \\
\hline $\begin{array}{l}\text { Różnica odległości między } \\
\text { poszczególnymi punktami } \\
\text { pomiarowymi, w kierunku } \\
\text { pionowym }\end{array}$ & $\Delta h_{i}=h_{s i}-h_{p i}$ \\
\hline
\end{tabular}

pionowym

Odległość między punk-

tem pomiarowym a płasz-

czyzną bazową (płaszczy-

znę bazową określano na

podst. punktów usytuowa-

nych na łożu montażowym)

Oznaczenia: $h_{\text {- }}$ odległości między punktami pomiarowymi w kierunku pionowym $(i=1, \ldots, n) ; A, B, C, D$ - współrzędne równania płaszczyzny bazowej; $x_{i}, y_{i}, z_{i}-$ współrzędne punktu pomiarowego; n - liczba punktów pomiarowych w szeregu siatki pomiarowej; indeksy dolne: $p$ - wartość mierzona przed spawaniem, s - wartość mierzona po spawaniu.

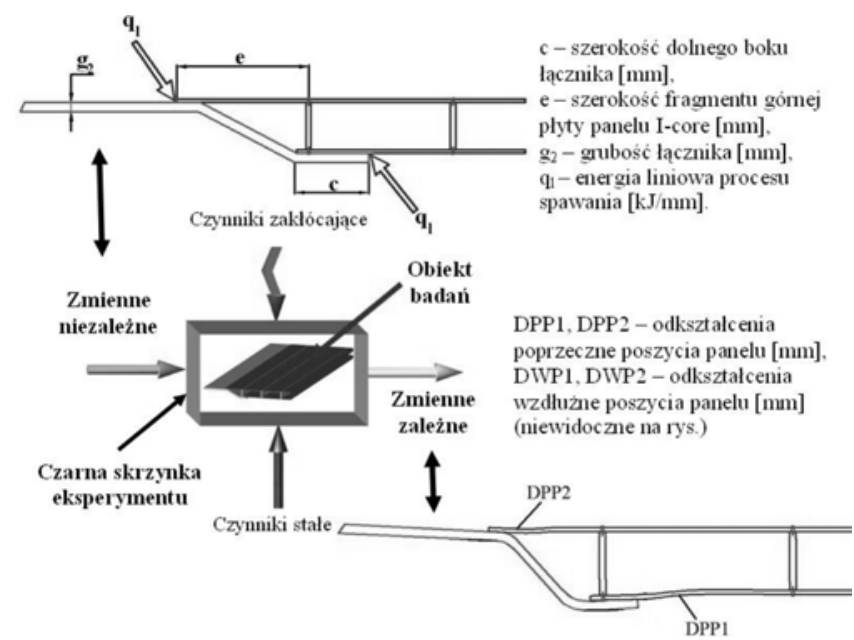

Rys. 5. Czarna skrzynka eksperymentu planowanego [2]

Fig. 5. Planned experiment black box [2]

Tablica V. Plan eksperymentu - wartości unormowane [2]

Tabl. V. Plan of the experiment - normalised values [2]

\begin{tabular}{|c|c|c|c|}
\hline $\begin{array}{c}\text { Nr eks- } \\
\text { pery- } \\
\text { mentu }\end{array}$ & $\begin{array}{c}\text { Energia } \\
\text { liniowa } \\
\mathrm{x}_{1}\left(\mathrm{q}_{1}\right)\end{array}$ & $\begin{array}{c}\text { Grubość } \\
\text { łącznika } \\
\mathrm{x}_{2}\left(\mathrm{~g}_{2}\right)\end{array}$ & $\begin{array}{r}\text { Szerokość dolnego boku } \\
\text { łącznika } \mathrm{x}_{3}(\mathrm{c}) \text { lub szero- } \\
\text { kość fragmentu górnej płyty } \\
\text { panelu l-core } \mathrm{x}_{3}(\mathrm{e})^{*}\end{array}$ \\
\hline 1 & -1 & -1 & -1 \\
\hline 2 & +1 & -1 & -1 \\
\hline 3 & -1 & +1 & -1 \\
\hline 4 & +1 & +1 & -1 \\
\hline 5 & -1 & -1 & +1 \\
\hline 6 & +1 & -1 & +1 \\
\hline 7 & -1 & +1 & +1 \\
\hline 8 & +1 & +1 & +1 \\
\hline
\end{tabular}

* W zależności od analizowanej postaci odkształcenia (patrz rys. 1 i 5). Wartości rzeczywiste poszczególnych zmiennych niezależnych, odpowiadające wartościom unormowanym, należą do następujących przedziałów: $q_{1} \in[0,4 ; 0,95], g_{2} \in[6 ; 10], c \in[45 ; 75]$, e $€[60 ; 110]$. Zakresy zmian poszczególnych zmienych niezaleznych podano w następujących jednostkach: $q_{1}[\mathrm{~kJ} / \mathrm{mm}], g_{2}[\mathrm{~mm}]$, c [mm], e [mm].

\section{Wyniki badań}

Jako aproksymowaną funkcję obiektu badań przyjęto wielomian ze składnikami liniowymi oraz interakcjami pierwszego rzędu, postaci:

$$
y_{i}=b_{0}+b_{1} x_{1}+b_{2} x_{2}+b_{3} x_{3}+b_{12} x_{1} x_{2}+b_{13} x_{1} x_{3}+b_{23} x_{2} x_{3}
$$

gdzie: $y_{i}$ - wyznaczana zmienna zależna (postać odkształcenia panelu l-core); $b_{0}, b_{1}, b_{2}, b_{3}, b_{12}, b_{13}, b_{23}$ - współczynniki regresji; $x_{1}, x_{2}$, $\mathrm{x}_{3}$ - zmienne niezależne wybrane do eksperymentu (rys. 5, tabl. V).

Następnie wyznaczono poszczególne współczynniki regresji występujące w równaniu (4), dla każdej $z$ analizowanych postaci odkształceń (przy poziomie istotności $\alpha=0,05$, tzn. współczynniku ufności 95\%).

W celu uzyskania zależności zawierających tylko współczynniki istotne zastosowano metodę regresji 
krokowej (postępującej lub wstecznej). Ostatecznie wybierano metodę dającą wyższe (bliższe jedności) wartości współczynników: R (współczynnika korelacji wielokrotnej), $R^{2}$ (kwadratu współczynnika korelacji wielokrotnej), Skoryg $\mathrm{R}^{2}$ (skorygowanego kwadratu współczynnika korelacji wielokrotnej).

Zestawienie porównujące wartości skorygowanego kwadratu współczynnika korelacji wielokrotnej oraz statystyk F-Snedecora dla analizowanych postaci deformacyjnych przedstawiono w tablicy VI, a zestawienie równań regresji aproksymujących wyznaczane postacie odkształceń spawalniczych panelu I-core - w tablicy VII.

Podsumowanie regresji wraz z wykazem istotnych zmiennych, dla wybranej formy deformacyjnej, pokazano w tablicy VIII. Wybrano zestawienie dla DWP2 jako deformacji, dla której wartość skorygowanego kwadratu współczynnika korelacji wielokrotnej mieści się na średnim poziomie wszystkich uzyskanych wartości tego współczynnika. Pełne tabele dla wszystkich analizowanych postaci odkształceń zamieszczono w [2]. O istotności współczynników równań regresji świadczą dane zestawione w tablicy VI. Dla wszystkich analizowanych postaci odkształceń [2]:

- Skorygowany kwadrat współczynnika korelacji wielokrotnej (Skoryg $\mathrm{R}^{2}$ ) waha się w granicach $(0,8299 \div 0,9552)$, co oznacza, że stopień dopasowania powierzchni regresji do danych doświadczalnych mieści się w przedziale $83 \div 95 \%$.

- Wartości statystyk F przekraczają wartości krytyczne $F_{k r}$, a wartość $p$ jest mniejsza od poziomu istotności $\alpha$.
$\mathrm{Na}$ tej podstawie stwierdzono, że wyznaczone równania regresji są istotne statystycznie i mogą być wykorzystane do prognozowania wartości zmiennych zależnych w funkcji przyjętych zmiennych niezależnych.

Na rysunkach 6 i 7 zamieszczono wykresy przedstawiające zgodność dopasowania wartości prognozowanych z wyznaczonymi eksperymentalnie. Umieszczając na osi odciętych wartości zmiennych zależnych, uzyskane w ramach eksperymentu, a na osi rzędnych wartości zmiennych zależnych, otrzymane $z$ równania regresji, dokonywano oceny rozmieszczenia aproksymowanych wartości na wykresie. Jeżeli wyniki ułożone są w pobliżu linii prostej, poprowadzonej z początku układu współrzędnych pod kątem $45^{\circ}$, oznacza to, że aproksymacja poprawnie prognozuje analizowane zależności.

$\mathrm{Na}$ podstawie analizy wykresów prognostycznych stwierdzono, że [2]:

- Najmniej punktów odbiegających od linii prognoz idealnych znajduje się na wykresach sporządzonych dla tych postaci odkształceń, które w wyniku analizy regresji uzyskały Skoryg. $\mathrm{R}^{2} \mathrm{o}$ wartości powyżej 0,9 (DPP1, DWP1).

- Dla postaci odkształceń, które uzyskały mniejszą wartość Skoryg. $R^{2}$, tj. równą 0,9 (DWP2) lub poniżej wartości 0,9 (DPP2), punktów odbiegających od linii prognoz idealnych jest więcej (w zależności od postaci odkształcenia). Przedstawiają to pola rozrzutu wyników (zaznaczone na wykresach liniami przerywanymi).

Tablica VI. Porównanie wartości: skorygowanego kwadratu współczynnika korelacji wielokrotnej oraz statystyk F-Snedecora [2] Table VI. Comparison values: corrected square of coefficient of multiple correlation and F-Snedecor statistic [2]

\begin{tabular}{|c|c|c|c|}
\hline $\begin{array}{c}\text { Symbol zmiennej } \\
\text { zależnej }\end{array}$ & $\begin{array}{c}\text { Wartość } \\
\text { Skoryg. } R^{2}\end{array}$ & $\begin{array}{c}\text { Wartość statystyki } F \text {, wyznaczona } \\
\text { na podst. analizy regresji }\end{array}$ & $\begin{array}{c}\text { Wartość krytyczna } F_{k r}, z \text { tablic statystycznych } \\
\text { (dla poziomu istotności } \alpha=0,05)\end{array}$ \\
\hline$y_{\text {DWP1 }}$ & 0,92485 & $F(3,4)=29,715 ; p<0,00341$ & $F(3,4)=6,59$ \\
\hline$y_{\text {DPP1 }}$ & 0,95520 & $F(4,3)=38,312 ; p<0,00657$ & $F(4,3)=9,12$ \\
\hline$y_{\text {DWP2 }}$ & 0,90000 & $F(3,4)=22,000 ; p<0,00600$ & $F(3,4)=6,59$ \\
\hline$y_{D P P 2}$ & 0,82999 & $F(3,4)=12,391 ; p<0,01711$ & $F(3,4)=6,59$ \\
\hline
\end{tabular}

Tablica VII. Zestawienie równań regresji aproksymujących wyznaczane postacie odkształceń spawalniczych panelu I-core (na podst. [2]) Table VII. Composition of regress equations approximated of determine types of welding distortions of I-core panel (on the basis of [2])

\begin{tabular}{|l|cr|}
\hline \multicolumn{1}{|c|}{ Symbol postaci odkształcenia } & Postać równania regresji & $(5)$ \\
\hline DWP1 & $y_{D W P 1}=b_{0}+b_{1} q_{l}+b_{13} q_{l} c+b_{23} g_{2} c$ & $(6)$ \\
\hline DPP1 & $y_{D P P 1}=b_{0}+b_{1} q_{l}+b_{3} c+b_{12} q_{1} g_{2}+b_{23} g_{2} c$ & $(7)$ \\
\hline DWP2 & $y_{D P P 1}=b_{0}+b_{1} q_{l}+b_{3} c+b_{12} q_{l} g_{2}+b_{23} g_{2} c$ & $(8)$ \\
\hline DPP2 & $y_{D W P 2}=b_{0}+b_{1} q_{l}+b_{2} g_{2}+b_{12} q_{l} g_{2}$ & \\
\hline Oznaczenia: $\mathrm{b}_{0}, \mathrm{~b}_{1}, \mathrm{~b}_{2}, \mathrm{~b}_{3}, \mathrm{~b}_{12}, \mathrm{~b}_{13}, \mathrm{~b}_{23}$ - współczynniki regresji, c, e, $\mathrm{g}_{2}, q_{1}-$ zmienne niezależne wybrane do eksperymentu (rys. 5 i tabl. V).
\end{tabular}

Tablica VIII. Zestawienie istotnych zmiennych w metodzie regresji krokowo postępującej dla DWP2 [2]

Table VIII. Composition of significant variables for performed of progressive regress selection method, for DWP2 [2]

Podsumowanie regresji zmiennej zależnej; $y_{\text {DwP2 }} R=0,97100831 R^{2}=0,94285714$ Skoryg $R^{2}=0,9, F(3,4)=22 p<0,006$ Błąd standardowy estymacji: 0,125

\begin{tabular}{|c|c|c|c|c|c|c|}
\hline $\mathrm{N}=8$ & Beta & Bł. Stand. Beta & B & Bł. Stand. B & $\mathrm{t}(4)$ & Poziom $\mathrm{p}$ \\
\hline W. wolny & & & $-1,05000$ & 0,507599 & $-2,06856$ & 0,107405 \\
\hline $\mathrm{x} 1$ & 2,19740 & 0,492805 & 3,25000 & 0,728869 & 4,45896 & 0,011169 \\
\hline $\mathrm{x} 2$ & 1,21702 & 0,332952 & 0,22500 & 0,061555 & 3,65525 & 0,021671 \\
\hline $\mathrm{x} 1 \cdot \mathrm{x} 2$ & $-1,64786$ & 0,582605 & $-0,25000$ & 0,088388 & $-2,82843$ & 0,047421 \\
\hline
\end{tabular}


- Pola rozrzutu pokazują również, że najbardziej dokładne prognozy osiągnięto dla wyników przedstawiających średnie wartości odkształceń.

- Maksymalna różnica między wartością prognozowaną a wyznaczoną eksperymentalnie wynosi $0,29 \mathrm{~mm}$ (dla DWP1).

$\mathrm{Na}$ rysunkach $8 \div 10$ przedstawiono wyniki badań eksperymentalnych dla wybranej próbki (oznaczonej DI03 - układ eksperymentalny dla tej próbki odpowiada wartościom $\mathrm{nr} 6 \mathrm{z}$ tabl. V). Na rysunkach 8 i 9
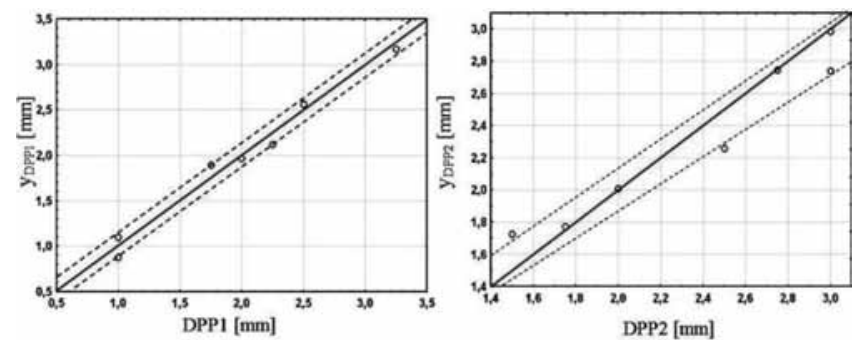

DPP1, DPP2 - wartości wyznaczone eksperymentalnie. $y_{D P P 1}, Y_{D P P}$ - wartości aproksymowane

Rys. 6. Prognozy dla analizowanych poprzecznych postaci odkształceń panelu l-core [2]

Fig. 6. Predictions for analyzed transverse types of distortions of I-core panel [2]
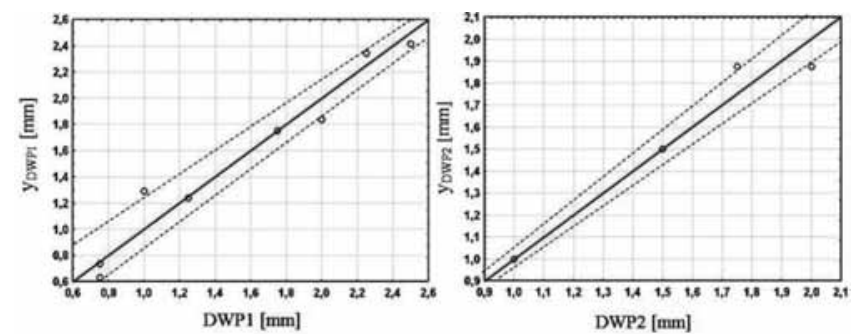

DIVP1. DIVP2 - wartości wyznaczone eksperymentalnie,

YDWP1, YDWP2 - wartosci aproksymowane

Rys. 7. Prognozy dla analizowanych wzdłużnych postaci odkształceń panelu I-core [2]

Fig. 7. Predictions for analyzed longitudinal types of distortions of I-core panel [2]

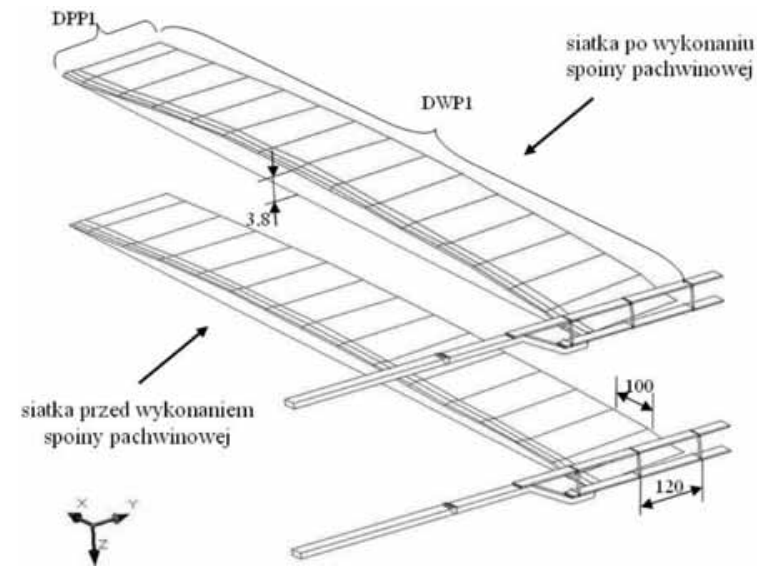

Rys. 8. Odkształcenia na dolnej powierzchni panelu l-core (przed wykonaniem oraz po wykonaniu spoin pachwinowych) [2]

Fig. 8. Distortions on I-core lower surface (before and after making of fillet welding) [2] sa analizowane formy odkształceń w postaci tzw. siatek 3D (sporządzonych na podstawie odczytów w punktach pomiarowych), na których celem otrzymania wyraźniejszego efektu wizualnego przeskalowano wartości występujące na osi „z” (wartości deformacyjne) x10. Wartości wzdłuż pozostałych osi układu pozostawiono bez zmian (punkty powstałe $z$ przecięć linii siatek odpowiadają punktom pomiarowym na powierzchniach próbki), nie uwzględniono też efektu odbicia lustrzanego odczytu z przyrządu pomiarowego.

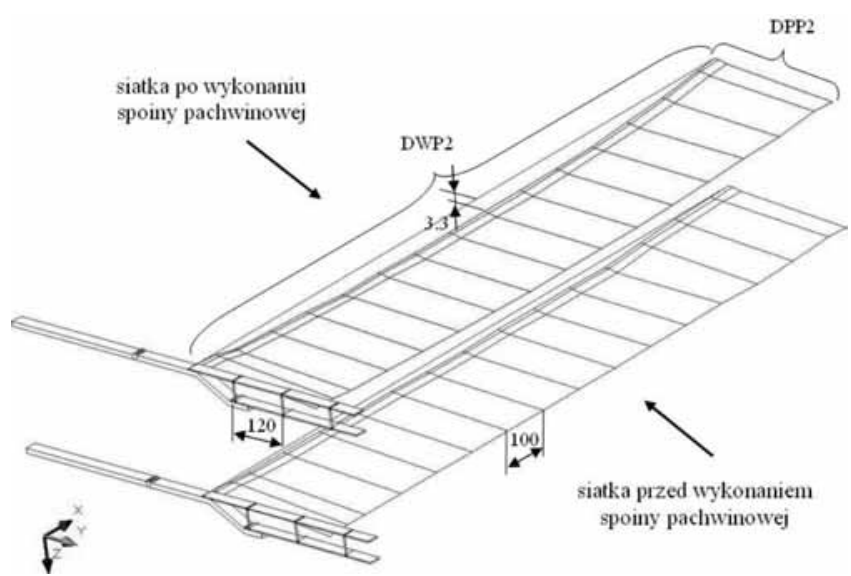

Rys. 9. Odkształcenia na górnej powierzchni panelu l-core (przed wykonaniem oraz po wykonaniu spoin pachwinowych) [2]

Fig. 9. Distortions on I-core upper surface (before and after making of fillet welding) [2]

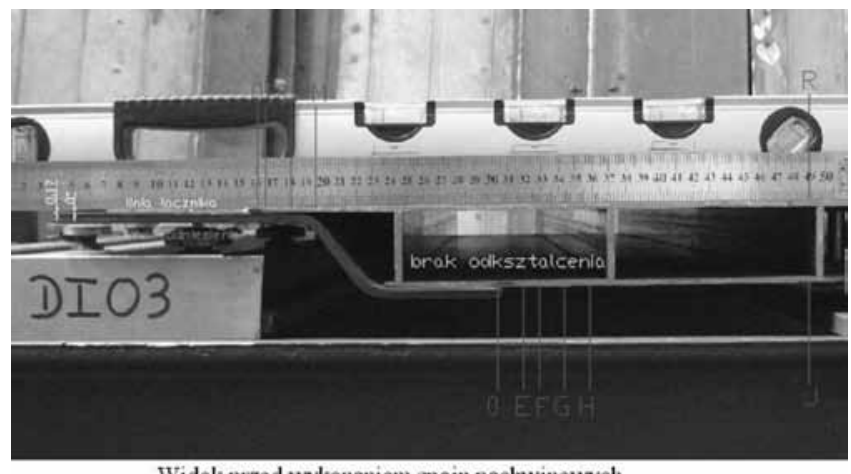

Widok przed wykonaniem spoin paclnwinowych

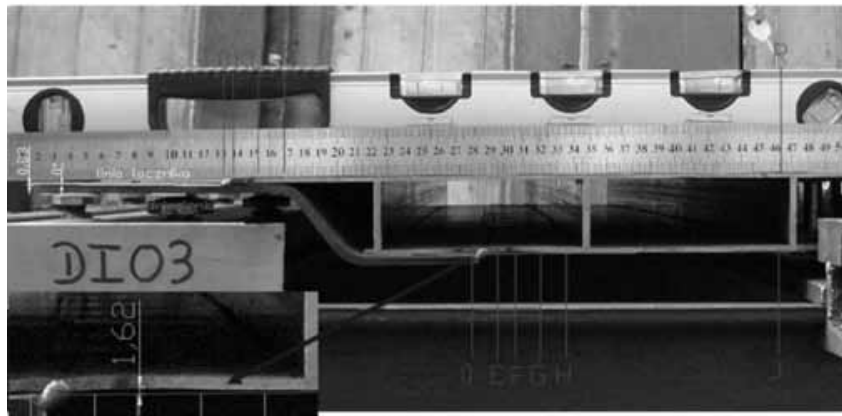

O E F G H $\begin{gathered}\text { Widok po wykonaniu spoin pachwinowych } \\ 0 \div \mathrm{R} \text {-rzędy siatki pomiarowej. } \\ \text { DI03-oznaczenie próbki }\end{gathered}$

Rys. 10. Odkształcenia panelu I-core [2]

Fig. 10. Distortions of I-core panel [2] 


\section{Wnioski}

Ocena wyników eksperymentu planowanego umożliwia opracowanie modeli matematycznych do prognozowania postaci odkształceń spawalniczych paneli I-core. Na podstawie przedstawionych wielomianów aproksymacyjnych można dokonać prognoz wartości postaci odkształceń dla dowolnej kombinacji parametrów technologiczno-konstrukcyjnych. Jedynym warunkiem, jaki musi zostać spełniony podczas takich prognoz, jest przynależność tych parametrów do przestrzeni definicyjnej realizowanego eksperymentu.
Posługując się równaniami aproksymacyjnymi można ponadto pokazać, które z uznanych za istotne parametrów mają decydujący wpływ na otrzymaną postać odkształcenia.

Opracowanie metody prognozowania odkształceń spawalniczych pozwoli na dokładne określenie przydatności montażowej węzła hybrydowego, a w konsekwencji umożliwi sterowanie technologicznością konstrukcji na etapie jej wytwarzania.

\section{Literatura}

[1] Urbański T.: Węzeł hybrydowy - technologiczność wielkogabarytowych konstrukcji spawanych - wprowadzenie, Przegląd Spawalnictwa Nr 11/2010, s. 21-25.

[2] Urbański T.: Metoda prognozowania odkształceń spawalniczych węzła hybrydowego na podstawie badań eksperymentalnych, Rozprawa doktorska, Zakład Konstrukcji Mechaniki i Technologii Okrętów, Wydział Techniki Morskiej, Zachodniopomorski Uniwersytet Technologiczny w Szczecinie, Szczecin 2009.

[3] Pyszko R.: Zastosowanie stalowych paneli typu sandwich w konstrukcjach okrętowych i oceanotechnicznych, Rozprawa doktorska, Katedra Technologii Okrętu, Systemów Jakości i Materiałoznawstwa, Wydział Oceanotechniki i Okrętownictwa Politechniki Gdańskiej, Gdańsk 2006.

[4] http://www.meyerwerft.de.

[5] Kozak J.: Stalowe panele SANDWICH - alternatywa dla klascznej konstrukcji, warsztaty nt. „Materiały kompozytowe w budowie statków" zorganizowane przez Centrum Techniki Okrętowej S. A., Gdańsk, 17 czerwiec 2005.

[6] Best Practice Guide for Sandwich Structures in Marine Applications (Document of SANDCORE Project).

[7] Sandwich design principles and prototype designs (Document of SANDWICH Project).

[8] Iwańkowicz R., Rutkowski R., Urbański T., Graczyk T., Jastrzębski T.: Review of manufacturing technologies for metalic structures in shipbuilding (Document of MARSTRUCT Project, http://mar.ist.utl.pt).

[9] That-Ching Fung, i in.: Shear Stiffness for C-core Sandwich Panels, Journal of Structural Engineering, August 1996, s. 958-966.

[10] Lok T.S., Cheng Q.H.: Elastic Stiffness Properties and Behavoiur of Truss-core Sandwich Panels, Journal of Structural Engineering, May 2000, s. 552-559.

[11] Kujala P., Romanoff J., Tabri K., Ehlers S.: All Steel Sandwich Panels - Design Challenges for Practical Application on Ships, 9th Symposium on Practical Design of Ships and Other Floating Structures, Lubeck-Travemuende, Germany 2004.

[12] Zenkert D., Kolsters H., Wennhage P.: Practical design solutions for laser-welded sandwich panels, Public conference, Papenburg, Germany, 24 October 2003 (http://sandwich. balport.com).
[13] Kozak J.: Fatigue tests of steel sandwich panel, Marine Technology V, Proc. of the Fifth International Conference on Marine Technology ODRA'03, Szczecin, 28-30 May 2003, WITPress - Southampton \& Boston 2003.

[14] Kujala P., Kotisalo K.: Fatigue Strength Testing of Laser WeIded all Steel Sandwich Panels for Ships, Maritime Research News, Vol. 11/ISSN 0784-6010, 1997.

[15] Metschkow B., Kozak J.: Quantitative tests of natural-scale SANDWICH models, Public Conference, Papenburg, Germany, 24 October 2003 (http://sandwich.balport.com).

[16] Ehlers S., Kujala P., Klanac A.: Fatigue testing of joints and comparation with FE-calculations, Advanced composite sandwich steel structures (http://sandwich.balport.com).

[17] Kujala P., Ehlers S.: Sandwich joint design principles and design catalog, Advanced composite sandwich steel structures (http://sandwich.balport.com).

[18] Kujala P.: Corrosion testing of steel sandwich panels, Maritime Research News, Vol. 15/ISSN 0784-6010, 2001.

[19] Tabri K.: Local impact strength of all steel sandwich panels, Maritime research news, vol. 17/ISSN 0784-6010, 2003.

[20] Masubuchi K.: Analysis of Welded Structures, Massachusetts Institute of Technology, USA, 1980, Pergamon Press.

[21] Metschkow B.: Ocena wielkości odkształceń spawalniczych na podstawie obliczeniowej metody inżynierskiej, XX Sesja Naukowa Okrętowców, Gdańsk 2002.

[22] Myśliwiec M.: Cieplno-mechaniczne podstawy spawalnictwa, Wyd. II WNT, Warszawa 1972.

[23] Ranatowski E.: Elementy fizyki spajania metali, Wydawnictwa Uczelniane Akademii Techniczno-Rolniczej, Bydgoszcz 1999.

[24] Montgomery D.C.: Design and analysis of experiments. John Wiley \& Sons, Inc. fifth edition, New York, 2001.

[25] Polański Z.: Planowanie doświadczeń w technice, PWN, Warszawa 1984.

[26] Dobosz M.: Wspomagana komputerowo statystyczna analiza wyników badań, Akademicka Oficyna Wydawnicza EXIT, Warszawa 2004.

[27] Kołodziński E.: Symulacyjne metody badania systemów, PWN, Warszawa 2002.

[28] Oktaba W.: Elementy statystyki matematycznej i metodyka doświadczalnictwa, PWN, Warszawa 1974.

[29] Nikiel G.: Opracowanie statystyczne wyników badań doświadczalnych z wykorzystaniem programu ReGreg (http://www. ath.bielsko.pl).

[30] http://www.statsoft.pl 